\title{
Study on the Development Strategy of Ant Financial
}

\author{
Ximeng Zhang ${ }^{1} \&$ Myeong Cheol Choi ${ }^{1}$ \\ ${ }^{1}$ Department of Global Business, Gachon University, South Korea \\ Correspondence: Myeong Cheol Choi, Department of Global Business, Gachon University, South Korea.
}

Received: April 30, 2019

Accepted: May 30, 2019

Online Published: June 11, 2019

doi:10.5430/ijfr.v10n5p262

URL: https://doi.org/10.5430/ijfr.v10n5p262

\begin{abstract}
Convergence of Internet technology and traditional financial industry has created a new field of Internet finance. Nowadays, China has a very large Internet user base and application market. With the application and development of the Internet, China has become one of the most developed countries that use Internet banking services and has the highest number of Internet finance users. Ant Financial is the first to enter the Internet financial market, and has now become a representative of China's Internet finance industry due to its extensive layout and rich business. Most of the previous research has only studied a part of Ant Financial without an analytical framework. Therefore, this study intends to investigate the history, development process, and success factors of Ant Financial. The contents of this paper are as follows. First, the development process and the current situation of Ant Financial Services are expounded. Second, the advantages and disadvantages of the current development process are analyzed by the SWOT analysis technique. Through the comparison of the research results, the guiding opinions for the development of Ant Financial Services are proposed. Finally, summary of the success reasons and future prospects for development are presented.
\end{abstract}

Keywords: Alibaba, Ant Financial, Internet finance, SWOT analysis

\section{Introduction}

With the advent of the era of big data, almost all industries have changed because of the widespread use of computers and the Internet. Finance is the center of modern economy, and banks play an important role in the financial industry. The collision of Internet technology and the traditional financial industry has led to the emergence of a new field, namely Internet finance, which has developed rapidly in the last few years and has brought convenience to people. After a period of development, people have tried the benefits brought by Internet finance and found that Internet finance has its unique advantages. The low cost, high efficiency and wide coverage of Internet finance are indeed superior to traditional finance.

Ant Financial is now gaining attention in China, and some scholars have conducted research on it. Ma and Wei (2018); Michael, Justina and (Olabode 2018) analyzed the business model of Ant Financial and made suggestions on how to further promote the development of "Internet plus" inclusive finance.

Zhang and Wang (2018) compared Ant Financial and Jingdong financial operation models by focusing on the analysis of their financing business.

Xia, Wang, and Li (2015); Bugu and Yucheng (2018) expounded the development status and history of Ant Financial and put forward guiding opinions on its future development. Some studies are still analyzing the growth of Ant Financial. However, considering the influence of Ant Financial, the amount and depth of research are still inadequate.

Most of the previous research has only explained the history, development status, and business scope of Ant Financial. But there are limitations in analyzing a business model without a sophisticated analytical framework. Moreover, they considered Ant Financial Services only as a technology service enterprise. However, its success reason and future development directions are not limited to a specific business.

Ant Financial is developing rapidly, and its development strategy is closely related to social development needs and national policies. Thus, this study was carried out as follows. First, the history of Ant Financial Services is briefly described. Second, the SWOT analysis of Ant Financial Services is carried out using the most recent data. Finally, the results of the analysis are used to provide a theoretical support for the development of China's Internet finance 
industry (Amogechukwu and Unoma 2017).

\section{Ant Financial History}

According to the reported data, the Taobao transaction amount was only 0.227 billion yuan (RMB) in 2003. At that time, the behavior of deceiving consumers in the transaction process was frequent in China. In December 2004, Alibaba's Taobao launched Alipay as a third-party payment platform to solve the problem of honesty payment, Alipay dispelled the earliest Chinese people's scruples in the online shopping process. After breaking the bottleneck, Taobao's transaction volume exceeded 1 billion yuan (RMB) in 2004; with the rapid increase in Taobao's trading volume, Alipay's business volume has also grown geometrically.

In 2008, Alipay was upgraded from a payment platform to a comprehensive convenience service platform through which people can pay utility bills for water, electricity, coal, communications, etc. In order to meet the needs of more users, Ant Financial Co., Ltd. was officially established in 2014. With the mission of "bringing more equal opportunities for the world," Ant Financial is committed to building an open and shared credit system and financial service platform through technological innovation capabilities.

This financial service platform provides safe and convenient financial services to consumers and small and micro enterprises worldwide. On November 2, 2018, Alibaba released its second quarter results for FY 2019. The financial report shows that by the end of September 2018, Alipay had more than 700 million annual active users in the country, and $70 \%$ of the users use three or more Alipay services. By the end of 2017, the number of Alipay users was 520 million, which means that the number increased by $34.5 \%$ in the first 10 months of 2018 (Alibaba Group, 2018).

Table 1. Ant Financial development graph

\begin{tabular}{ll}
\hline Time & Event \\
\hline 2003.10 .18 & Taobao launched secured transactions \\
\hline 2004.12 .08 & Alipay was established \\
\hline 2005.6 .20 & In addition to Taobao, Alipay accessed other websites \\
\hline 2006.6 .31 & Mobile client launched \\
\hline 2006.11 .01 & Alipay cooperated with 36 banks \\
\hline 2010.7 .01 & Barcode payment \\
\hline 2011.5 .26 & First third-party payment license \\
\hline 2013.6 .17 & Yu Ebao online \\
\hline 2015.10 .16 & Ant financial established \\
\hline 2016.3 .03 & Completion of A-round financing \\
\hline 2016.4 .26 & Mybank established \\
\hline 2017.1 .19 & Completed its US $\$ 4.5$ billion Series B fundraising \\
\hline 2018.6 .08 & Completed its US $\$ 14$ billion fundraising \\
\hline
\end{tabular}

Source: Ant Financial's homepage

\section{Ant Financial SWOT Analysis}

\subsection{Strengths Analysis}

China's Internet infrastructure construction has been continuously upgraded. As of June 2018, the numbers of Internet users in China were 802 million, and the Internet penetration rate was $57.7 \%$. In the first half of 2018, there were 29.68 million new Internet users, an increase of 3.8\% since December 2017. The number of mobile Internet users in China reached 788 million, and the proportion of Internet users accessing the Internet through mobile phones was also as high as 98.3\% (Cyberspace Administration of China, 2018; Ozkurt \& Alpay 2018). The earliest business of Ant Financial is to provide a safe payment method for Taobao customers. The user can experience the convenience 
of shopping without the traditional bank's cumbersome operation process. Moreover, this payment method is no longer restricted by geography, and payment efficiency has greatly improved.

After discovering the gap in China's online payment market, Alipay has cooperated with many banks, financial institutions, and convenience service organizations in China to expand its business scope in all aspects. The business segment extends to areas such as payment, wealth management, insurance, and microfinance. Ant Financial has built a bridge among all walks of life, from enabling a single third payment platform to a comprehensive one-stop service platform (Ali \& Haseeb, 2019; Hsiao,et.al 2017).

Second, the huge customer base and huge transaction volume are the biggest advantages for the development of Ant Financial. Ant Financial quickly opened its market with Alibaba's Taobao. The annual transaction volume during the "double eleven" period (November 11th) was as high as 100 billion yuan (RMB). In 2018 double eleven (November 11, 2018), the turnover of goods settled with Alipay reaching 213.5 billion yuan (RMB) (Alibaba Group, 2018; Jafari, Jafari and Kafipour 2018). Alipay separated from Taobao once it developed well. However, it not only promotes itself with Taobao but also cooperates with other domestic e-commerce companies, including almost all domestic e-commerce companies. With such a huge customer base, Ant Financial can accurately retrieve customer needs through big data analysis and conduct targeted marketing for customers, which not only reduces costs but also avoids customer resentment.

The primary responsibility of Ant Financial is providing safe and convenient inclusive financial services to consumers and micro enterprises worldwide. Because of the high threshold of traditional bank loans in China, many small and micro enterprises face difficulties in obtaining loans from banks. Ant Financial has explored this gap in the loan market, and its own characteristics of light assets and low cost have the advantages of developing long tail customers.

\subsection{Weaknesses Analysis}

At present, China's information and communication technology field is developing rapidly. Although Internet finance has changed people's lives drastically, the hidden problems behind the development of Internet finance cannot be underestimated. Once systemic risks accumulate over a long period of time, it is very likely that a chain reaction will occur, leading to a national Internet financial crisis.

Because of the lack of effective supervision of Internet finance, the capital chain becomes relatively fragile. Ant Financial uses its three small loan companies as its source of funds, which borrow from banks with a maximum capital of 150\%. In 2013, Ant Financial was listed in the Shenzhen Stock Exchange Center. It raised more than 9 billion yuan (RMB) through transfer of assets to form the operating mechanism of "Merchant $\rightarrow$ E-commerce platform $\rightarrow$ Ali small loan $\rightarrow$ Small loan company $\rightarrow$ Bank/broker." If an abnormality occurs, it will result in liquidity risk and trigger a danger of capital loss (Jermsittiparsert, 2016; Goral \& Akgoz 2017; Weng Lei, 2018; Hassan, et.al 2018).

China's current traditional banks have joined and used the credit system of the People's Bank of China, which has accumulated rich customer resources for many years and has a long history. The Sesame Credit of Ant Financial is the only institution with a personal credit license, and its credit system has not yet been fully improved. The most typical case caused by the imperfect credit system is the "Qiao Xing Debt," which occurred in December 2016. Since December 2014, the company under the Guangdong Private Enterprise Qiaoxing Group, namely Qiao Xing Telecom, has issued two-year private debt through the equity trading center of Guangdong Financial High-tech Zone, with a total principal and interest of 1.146 billion yuan (RMB). The private debt was released by the bond underwriter Guangdong Stock Exchange on the Internet distribution platform "Zhao Cai Bao," Until December 2016, the 1 billion yuan (RMB) private debt was not payable, and individual investors undoubtedly became the biggest victims of this incident.

\subsection{Opportunity Analysis}

The development of Internet technology has changed the consumption behavior of Chinese people and created a huge space for the development of e-commerce. Alibaba's success not only provides Taobao with a customer base that grows exponentially every year, but also provides more business opportunities for micro enterprises and individual merchants. China has formed a nationwide online payment service in the past two years, from shopping malls to small roadside fruit and fast food stalls; thus, e-commerce and society have been tightly integrated.

Ant Financial has undoubtedly become a giant of Chinese Internet market. More and more overseas companies are seeking to partner with it. The overseas business of Ant Financial is divided into two ways: the first is to provide overseas services for Chinese people, so that Chinese people can use Alipay overseas. By the end of 2017, Alipay has 
covered 36 countries. The second is the launch of localized investment and joint venture.

Ant Financial has already supported nine local Alipay wallets in nine countries in Southeast Asia, such as India's Paytm and Indonesia's Emtek. Compared with other payment companies, the core advantages of Ant Financial are its capital quantity and technical experience as well as its experience in helping investment companies gain first-mover advantage. For example, with regard to Paytm in India, in which Ant Financial has invested, after one year of investment, Paytm's system has evolved from a million-level processing capacity to an architecture that can carry billions of processing. The payment risk rate has dropped from a few percent to one in 10,000 (Gyebi, Owusu \& Etroo 2013; Mao Lin, 2018).

\subsection{Threats Analysis}

Traditional banks have been affected by Internet finance in recent years, and their performance is not as good as that before. In order to stabilize their own status, all traditional Chinese banks have also begun to reform and innovate. In order to break the restrictions on users' space and time, major banks in China have also launched their own mobile banking and online banking facilities, and even emulated Alipay to add convenience payment functions. In order to increase their competitiveness, users can obtain additional benefits through mobile banking.

Although Ant Financial has developed rapidly in the last two years, it can be regarded as a unicorn in the Chinese Internet industry. However, because of the huge interest and the low threshold of the Internet finance industry, many companies have tried to join and seize the market shares.

According to the analysis report released in the second quarter of 2018, the proportion of China's third-party payment institutions in the comprehensive payment market trading share is shown in Figure 1. Alipay's market share is $44.5 \%$, and China's Tencent Financial share is $30.8 \%$. Although other third-party payment platforms have not yet become an absolute threat to Alipay, in the face of an endless stream of entrants, there is still a certain threat to Alipay's dominance.

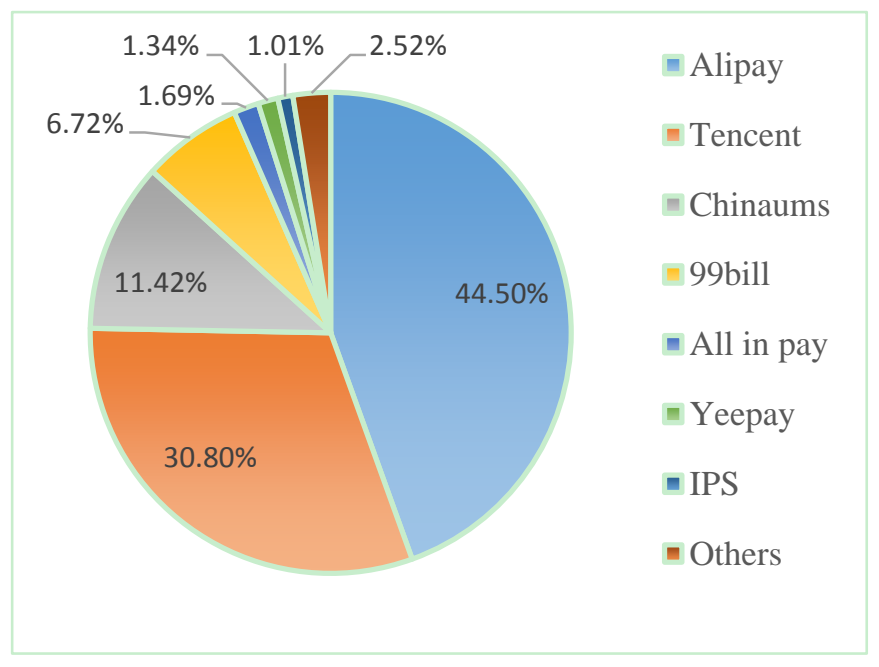

Figure 1. China's third-party integrated payment market transaction share in the second quarter of 2018

Source: Analysys

Table 2. Ant Financial SWOT analysis

\begin{tabular}{lll}
\hline External & Strength & Weakness \\
\cline { 2 - 3 } Internal & $\begin{array}{l}\text { Increase of China's internet } \\
\text { penetration. }\end{array}$ & $\begin{array}{l}\text { The supervisory mechanism is not } \\
\text { perfect. } \\
\text { Substantial customer base. }\end{array}$ \\
China's unsound credit system \\
Accurate market positioning.
\end{tabular}


E-commerce becomes main stream consumption method in Chinese society.

Oversea market development space is huge.
Exploit more markets with huge Strength network security. customer resources.

Strengthen internal control.

Actively promote customer Exclusive investment products for different customer groups, in order to achieve different expected returns. service.

\begin{tabular}{|c|c|c|}
\hline Threat & ST & WT \\
\hline $\begin{array}{l}\text { Mobile services launched } \\
\text { traditional banks. }\end{array}$ & $\begin{array}{l}\text { Clarify the responsibility system } \\
\text { and handle legal disputes }\end{array}$ & $\begin{array}{l}\text { Strengthen network security and capital } \\
\text { security management. }\end{array}$ \\
\hline Stress of competitors. & $\begin{array}{l}\text { reasonably. } \\
\text { Constantly improve the quality of } \\
\text { products and services. }\end{array}$ & $\begin{array}{l}\text { Establish partnerships } \\
\text { competitors. }\end{array}$ \\
\hline
\end{tabular}

\section{Ant Financial Development Countermeasures and Recommendations}

Although China's Internet finance has experienced the stage of germination, start-up, and spurt, the country's Internet finance industry is still in the initial stage of development due to the imperfect regulatory system and credit system. As the representative of China's Internet finance, the problems faced by Ant Financial in the development process are also the epitome of the rapid development of China's Internet finance.

\subsection{Improve China's Internet Regulatory System}

Because of the wide range of Internet finance and the difficulty of supervision, China has not yet legally defined the rights and obligations, subject matter, and content of Internet financial transaction entities through legal forms. First, the Chinese government should fully understand the features of Internet finance and combine the current laws and regulations to identify the access terms, business scope, and regulatory standards for different businesses.

Second, the supervision over Internet financial transactions should be tightened, and there should be an increase in the penalty for Internet financial crimes. Moreover, the situation of personal information disclosure in China is a serious issue. The China Consumers Association conducted a survey with an "App Personal Information Disclosure" questionnaire from July 17 to August 13, 2018. Among 5458 valid responses, 85.2\% reported encountering the problem of personal information leakage (China Consumers Association, 2018).

China should pass new regulations that impose penalties on those who maliciously disclose personal information. Ant Financial Services should actively respond to national policies, achieve self-market standardization, and strive to promote the healthy development of China's Internet finance industry.

\subsection{Promote Internet Financial Technology Innovation}

All business activities use the commodity as the core of value to extract profits. The embodiment of the goods is not limited to the types of goods, and the intangible services and technologies can also be regarded as commodities. Regardless of whether it is facing a market demand or the competitive pressure brought by new entrants, the Internet finance industry needs to constantly develop new technology and recruit talents.

Ant Financial's "Ant Fortune" is a one-stop financial products supermarket; it currently integrates all the financial products of Ant Financial, but these products are not very different from those provided by traditional banks, which definitely hinders the promotion of Ant Fortune. In the future, Ant Fortune should use the big data calculations of Ant Financial Service to classify and analyze the investment habits, risk tolerance, and consumption power of users across different age groups and then provide customers with exclusive financial products and better services to customers through technology.

Ant Financial is a financial service-based technology company. The financial industry is only a small branch, and financial technology and services are its two main development directions. Ant Financial Services should increase investment in scientific research and introduce talents. At present, Ant Financial has predicted that artificial intelligence will be applied to all walks of life in the future; therefore, Ant Financial has established a technical team to study how to make machines more intelligent through big data and cloud computing.

\subsection{Improve China's Social Credit System}

The long-term development of Internet finance is inextricably linked to the construction of credit information systems. At present, the central bank's credit information system is only open to some commercial banks; thus, many 
Internet financial institutions can only rely on the information obtained by their own search as the basis for credit evaluation, which leads to decline in information credibility and increase in non-performing loan ratio.

In this context, in order to establish a sound social credit system, first, information and data sharing should be realized, the coverage of the credit information system should be expanded, and individual illegal acts should be blacklisted. Second, the promotion of credit law should be accelerated. Strict punishments should be given to untrustworthy and malicious leakers, so that the public can increase their awareness of social credit ratings.

\section{Conclusion}

This paper analyzes the advantages and disadvantages of Ant Financial through SWOT analysis and makes recommendations for its development. Although Internet finance originated from abroad, in recent years, with the increasing popularity of China's network facilities and financial innovation, China's Internet finance has entered into a rapid development stage. Ant Financial is the bellwether of the Internet finance industry, and its rapid development, large user base, and new technological ideas are second to none. As a result, Ant Financial can occupy the first place in China's Internet finance industry because of the following two reasons.

From the analysis of the external environment, first, market demand is the most important reason for the rapid development of Ant Financial and even China's Internet finance industry. Because the traditional Chinese banking sector has a high threshold, many small and medium enterprises find it difficult to obtain loans from banks. However, Ant Financial discovered this market and provides services for the "long tail customers" that are not valued in the financial market, thus filling the gap in traditional financial coverage.

Second, policy support has also helped the development of Ant Financial. The Chinese government has repeatedly mentioned Internet finance in its reports. To encourage continuous innovation and healthy development of Internet finance, with the approval of the State Council of China, on July 18, 2015, the Central Bank united more than 10 departments to issue the "Guiding Opinions on Promoting the Healthy Development of Internet Finance." At the Fourth Session of the 12th National People's Congress, Premier Li Keqiang emphasized in the government work report that Internet finance should be standardized and vigorously developed (Peng Ye, 2017; Ha \& Tran 2018). Internally, Ant Financial has positioned itself as a technology company and has taken "innovation" as its important development strategy, because only by mastering more advanced technologies can it break the patterns of the traditional financial industry. Further, the arrival of the era of big data and cloud computing has greatly contributed to the development of Ant Financial. Artificial intelligence has emerged in recent years as a product of big data and cloud computing. It can further reduce labor costs, improve service efficiency, and ultimately provide better services to customers.

Ant Financial has always responded to China's relevant policies and promoted the implementation of the "One Belt and One Road" policy, helping countries along the route to establish infrastructure for inclusive financial coverage with local characteristics through technology. While helping local business partners to grow, the international status and market value of Ant Financial Services has also improved. With the advent of the 5G era, Ant Financial has another new opportunity for development.

\section{References}

Ali, A., \& Haseeb, M. (2019). Radio frequency identification (RFID) technology as a strategic tool towards higher performance of supply chain operations in textile and apparel industry of Malaysia. Uncertain Supply Chain Management, 7(2), 215-226. https://doi.org/10.5267/j.uscm.2018.10.004

Alibaba Group. (n.d.). Alibaba Group Announces Quarterly Results for the End of September. Hangzhou. Retrieved November 2, 2018, from https://www.alibabagroup.com/cn/news/article?news=p181102

Alibaba Group. (n.d.). In 2018 double eleven (November 11, 2018), the turnover of goods settled with Alipay reaching 213.5 billion yuan (RMB). Retrieved November 2, 2018, from https://www.alibabagroup.com/cn/news/article?news=p181112

Amogechukwu, E. T., \& Unoma, C. R. (2017). Extent of Head Teachers' Utilization of Innovative Sources of Funding Primary Schools in Enugu State of Nigeria. Journal of Education and e-Learning Research, 4(2), 41-45. https://doi.org/10.20448/journal.509.2017.42.41.45

Bugu, Z. Y., \& Yucheng, H. (2018). An Empirical Analysis of the Factors Affecting the Profitability of China's Agricultural Listed Companies under the Background of Agricultural Modernization. International Journal of Applied Economics, Finance and Accounting, 2(1), 19-26. https://doi.org/10.33094/8.2017.2018.21.19.26 
China Consumers Association. (n.d.). App personal Information Disclosure Report. Retrieved August 29, 2018, from http://www.cca.org.cn/jmxf/detail/28180.html

Cyberspace Administration of China. (n.d.). The 42nd of "Statistical report on the development of Internet in China". Retrieved August 29, 2018, from http://www.cac.gov.cn/2018-12/25/c_1123900964.htm

Goral, R., \& Akgoz, E. (2017). Tourism Price Competition Index for National Destinations. Journal of Tourism Management Research, 4(1), 17-29. https://doi.org/10.18488/journal.31.2017.41.17.29

Gyebi, F., Owusu, M., \& Etroo, J. K. (2013). Foreign Direct Investment and Gross Domestic Product in Ghana. International Journal of Academic Research in Accounting, Finance and Management Services, 3(3), 256-65. https://doi.org/10.6007/IJARAFMS/v3-i3/153

Ha, T. P. T., \& Tran, M. D. (2018). Review of Impacts of Leadership Competence of Project Managers on Construction Project Success. International Journal of Emerging Trends in Social Sciences, 4(1), 15-25. https://doi.org/10.20448/2001.41.15.25

Hassan, K. H., Razak, M. F. A., Nordin, R., \& Rahim, R. A. (2018). Malaysia with the Trans-Pacific Partnership Agreement: Aftermath of the United States Withdrawal From the TPPA. International Journal of Asian Social Science, 8(10), 868-880. https://doi.org/10.18488/journal.1.2018.810.868.880

Hsiao, C. M., Zhang, W. F., Chiu, C. C., Huang, J. C., \& Huang, Y. L. (2017). The Enterprise Risk Management of Foreign Exchange Exposures: Evidence from Taiwanese Hospitality Industry. Asian Journal of Economics and Empirical Research, 4(1), 32-48. https://doi.org/10.20448/journal.501.2017.41.32.48

Jafari, S., Jafari, S., \& Kafipour, R. (2018). Iranian Housewives Motives for English Language Learning from a Discursive Psychology Perspective. International Journal of English Language and Literature Studies, 7(4), 138-149. https://doi.org/10.18488/journal.23.2018.74.138.149

Jermsittiparsert, K. (2016). Culture of 'Elephant front legs-hind legs': A debate on the actuality of sexual politics in Thai society. The Social Sciences, 11(1), 20-28.

Ma, G. Q., \& Wei, M. K. (2018). Exploring the Path of Promoting Inclusive Financial Development Based on Internet - Taking Ant Financial Service as an Example. Estate and Science Tribune, 4(17), 16-17

Mao, L. (2018). Ant Financial, Opportunities and threats to the rise of unicorns. Retrieved June 12, 2018, from https://new.qq.com/omn/20180612/20180612A0EB5C00

Michael, O., Justina, O., \& Olabode, D. (2018). Child Labour and Protection: An Exploration of Vulnerable Children in Lagos State, Nigeria. Humanities and Social Sciences Letters, 6(4), 171-179. https://doi.org/10.18488/journal.73.2018.64.171.179

Ozkurt, B., \& Alpay, C. B. (2018). Investigation of Proactive Personality Characteristics of the Students of High School of Physical Education and Sports through Various Variables. Asian Journal of Education and Training, 4(2), 150-155. https://doi.org/10.20448/journal.522.2018.42.150.155

Peng, Y. (2017). Research on Ant Financial's Innovation Impetus and Business Expansion Path, p. 57. Hu Nan University.

Weng, L. (2018).Research on the fusion of commercial banks and internet finance, p. 13. East China Jiao Tong University.

Xia, B. S., Wang, M. Y., \& Li, X. (2015).Research on the development status and trend of Ant Financial Service. Financial View, (12), 94-97.

Zhang, L. Y., \& Wang, Y. M. (2018). Research on Small and Micro Enterprise Financing Model under E-commerce Big Data Finance-Based on Comparison between Ant Financial Service and Jingdong Finance. Southwest Finance, (07), 53-59. 